\title{
Annual and Seasonal Size-frequency Changes of Trap-caught Lobsters (Homarus americanus) in the Bay of Fundy
}

\author{
D. A. Robichaud \\ Department of Fisheries and Oceans, Biological Station \\ St. Andrews, New Brunswick, Canada E0G 2X0 \\ and \\ A. Campbell \\ Department of Fisheries and Oceans, Pacific Biological Station \\ Nanaimo, British Columbia, Canada V9R 5K6
}

\begin{abstract}
Size and sex of trap-caught lobsters (Homarus americanus) were recorded on commercial and chartered boats from selected areas in the Bay of Fundy during 1979-88. Size-frequency distributions varied considerably between geographic areas, over fishing seasons and between years. A higher proportion of large, mature lobsters was caught in the upper reaches of the Bay of Fundy and Passamaquoddy Bay. In contrast, areas off Chance Harbour showed evidence of high recruitment and lobster landings were characterized by a large proportion of smaller lobsters close to the legal minimum size ( $81 \mathrm{~mm}$ carapace length). Some of the factors contributing to changes in size-sex of lobster catches were identified as: (1) seasonal deep-shallow migrations of mature lobsters during summer and autumn (June-November); (2) molting of prerecruits to recruits during summer; and (3) fishing mortality removing legal size lobsters during the fishing season. Egg hatching and egg extrusion in ovigerous females occurred 1-2 weeks earlier in the upper reaches of the Bay of Fundy (Alma), compared to the lower reaches (Chance Harbour).
\end{abstract}

\section{Introduction}

The American lobster (Homarus americanus) supported a fishery in the Bay of Fundy valued at $\$ 9.1$ million in 1988. Based on analyses of historical lobster landing patterns (Campbell and Mohn, 1983), adult lobster movement (Cooper and Uzmann, 1971; Krouse, 1980; Campbell, 1984), genetic similarities between coastal and offshore lobsters (Barlow and Ridgway, 1971; Tracey et al., 1975; Odense and Annand, MS 1978) and planktonic larval distribution (Stasko, 1980; Stasko and Campbell, 1980; Harding et al., 1983), the Bay of Fundy lobster fishery was considered to harvest a part of a single, larger lobster stock that included Maine and southwestern Nova Scotia (Campbell and Mohn, 1983).

Through the years, the size structure of lobster catches in different areas of the Bay of Fundy has undergone various changes. These changes can be attributed to a variety of factors such as fluctuation in recruitment, environmental (temperature) and physical (bottom type) factors (Fogarty, 1988; Campbell, 1989), and the fishery itself. The purpose of the present study was to describe the geographic, annual and seasonal changes which occur in the size-frequency distributions and catches of trap-caught lobsters from the Bay of Fundy. This study was also designed to assess the impact the lobster fishery could have on lobster size distributions and catches.

\section{Fishing areas}

\section{Methods}

The Bay of Fundy lobster fishery began in the late1800 s and evolved through various changes in fishing regulations and effort restrictions such as size limit, fishing seasons, trap limit, number of lobster fishermen and fishing boundaries. Today, the fishery is conducted in three lobster fishing areas (LFA), with autumn and spring fishing seasons in LFA 35, 36 and 38, while LFA 38 also has an offshore lobster fishery which begins during the autumn and continues through winter until spring (Fig. 1). In addition, LFA 38 has an inshore lobster fishery with unique characteristics which differentiate it from the other two areas. For these reasons, data from LFA 38 were not included in these analyses and will be analyzed in a separate study.

The fishing seasons are open for LFA 35 from 15 October to 31 December and from 1 March to 31 July, and for LFA 36 from the second Tuesday in November to 14 January and from 1 April to 29 June. Each area has 


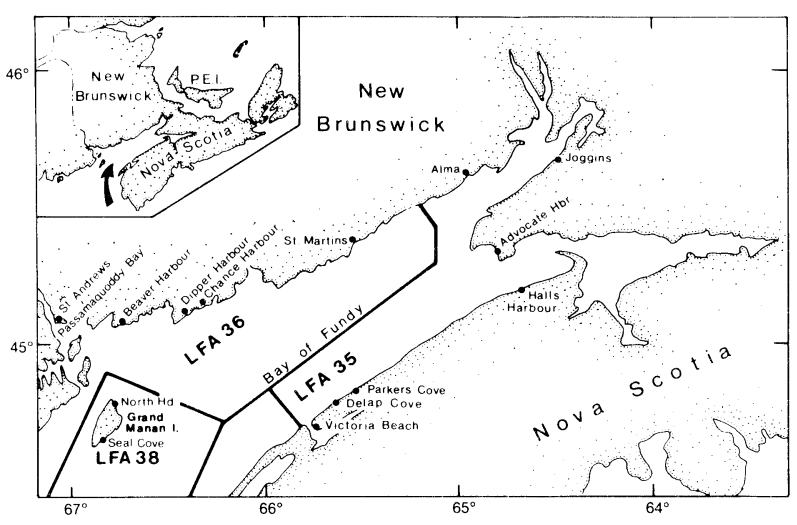

Fig. 1. Bay of Fundy lobster fishing areas and fishing ports near which at-sea samples were obtained

a 300 -trap limit, and during 1988, LFA 35 and 36 had 88 and 175 licensed lobster fishermen, respectively.

\section{Lobster landings}

Annual (calendar year basis) landings from 1892 (Fig. 2) and daily landings from sales slips from 1978 to 1988 were obtained from the Department of Fisheries and Oceans, Statistics Division, Halifax, Nova Scotia, Canada. Means of biweekly lobster landings for 1978-88 were calculated by adding the landings recorded on sales slips for each 2 -week fishing period and dividing the total by the number of years (Fig. 3). Due to lack of information on the number of fishing days and trap-hauls-per-day, effort could not be measured.

\section{At-sea sampling}

During 1978-88, the carapace (CL, mm) and sex of lobsters, and number of traps hauled were obtained by Department of Fisheries and Oceans personnel onboard various commercial lobster fishing boats and during research charters from various ports throughout the Bay of Fundy (Fig. 1). Lobster fishing grounds off the ports of Alma and Chance Harbour were sampled twice yearly since 1979. Each sample consisted of at least 100 trap-hauls or the measuring of at least 500 lobsters. The sampling was done within 2 weeks of the opening (October in LFA 35 and November in LFA 36) and the last 2 weeks at the end (June in LFA 36 and July in LFA 35) of each lobster fishing season. A large proportion of the lobster catch was landed during this time period (Fig. 3). Alma and Chance Harbour were also sampled during the closed lobster fishing season in August and September in 1978 and 1980. Lobster fishing grounds off other ports were sampled on an irregular basis, depending on manpower availability and because of the irregularities in the sampling, the data could not be included in the annual/seasonal analysis. However, in OctoberNovember 1979, all areas were sampled and geographical size differences were based on these data. All lobsters were caught at depths ranging between 9 and 5 $\mathrm{m}$.

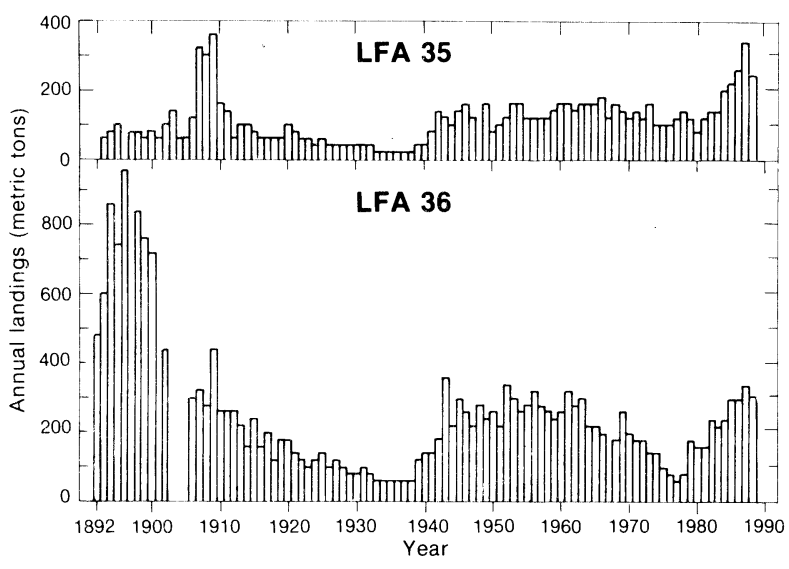

Fig. 2. Annual lobster landings (tons) for lobster fishing areas 35 and $36,1892-1988$

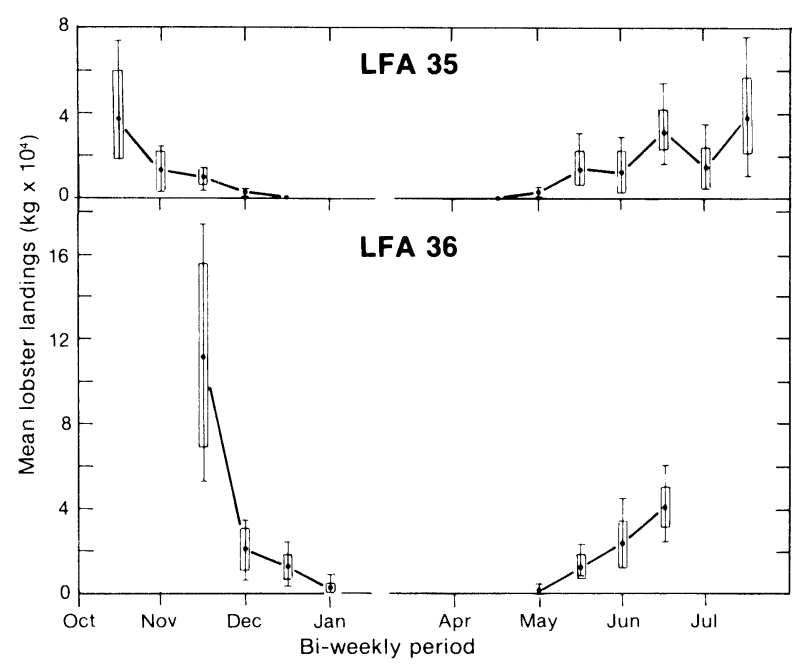

Fig. 3. Mean bi-weekly lobster landings for lobster fishing areas 35 and 36 over 10 years, 1977-88 (vertical lines are ranges; boxed areas are standard errors).

Trap selectivity can have some effect on the size of lobsters trapped (Elner, 1980; Miller, 1990). However, there were no significant differences in hoop size and lathe spacing of traps throughout the Bay of Fundy (Campbell, MS 1986), and a study by Miller (1989) showed that although traps were selective for large animals, size frequencies of catches nevertheless reflected differences among habitats. For these reasons, it was concluded that trap selectivity was probably not a major factor in determining the differences in size frequencies observed between areas.

Soak time, which ranged between 1 and 6 days, can influence the catch rate (Bennett, 1974; Bennett and Brown, 1979 for H. gammarus, and Thomas, 1973; Austin, 1977; Skud, 1979; Fogarty and Borden, 1980; Estrella and McKiernan, 1989; Miller, 1990 for $\mathrm{H}$. americanus). In the Bay of Fundy, because of high tides and strong currents, fishermen are limited in the number of traps hauled each day. For this reason and weather conditions, the majority of trap-hauls are made after 
2-3 soak days. However, soak days on a per-trap basis during each sampling trip were not recorded; therefore, catch-per-trap-haul could not be standardized with immersion time. Nevertheless, based on studies by Bennett and Lovewell (1977) for H.gammarus and Dow (1961) for $H$. americanus, we assumed that the effect of immersion time on the size composition of the catch would be negligible. In a recent comprehensive review of trap effectiveness, Miller (1990) stated that correction for soak time may be unnecessary for commercial catch data because fishermen use long enough soak time that catches are usually at asymptotic levels.

To investigate seasonal and annual variations in the size frequencies, three size categories were selected according to growth and maturity estimates derived by Campbell (1983): $75-80 \mathrm{~mm} \mathrm{CL}$ (prerecruit molt group); 81-94 mm CL (first molt into legal size); and $\geqslant 95 \mathrm{~mm} \mathrm{CL}$ (mature group). In the analysis, the selection of a narrow size range for the prerecruit molt groups (75-80 $\mathrm{mm} \mathrm{CL}$ ) was to minimize bias caused by an increased use of escape vents by fishermen during the last 5 years. Escape vents with an opening of 44.5 $\mathrm{mm}$ wide by $127 \mathrm{~mm}$ long (which are in use by some of the fishermen in the Bay of Fundy) allow over $50 \%$ of lobsters under $75 \mathrm{~mm} \mathrm{CL}$ to escape (Krouse and Thomas, 1975; Krouse, 1978).

Sex ratios were calculated as a percentage by dividing the number of males or females by the total number of lobsters, including berried (ovigerous) females, in any specified size category. Proportion of berried females was calculated from the total number of females in each specified size category. Eggs of berried females were classified as "old" if they contained developed embryos or empty egg cases and as "new" if they had recently been extruded, with no embryo or eye pigmentation visible.

\section{Data analysis}

The mean numbers of lobsters per-trap-haul were calculated by dividing the total number of lobsters in the catch by the total number of traps after transforming the data using In $(X+1)$; geometric means are the retransformed means of the logarithmically transformed variables. Unless stated otherwise, arithmetic means are reported.

Possible significant differences in monthly or yearly mean number of lobsters per-trap-haul for a specified size category were investigated by "one-way" analysis of variance, combined with a Duncan test (Duncan, 1955) after In (X+1) transformation.

\section{Results}

\section{Lobster landings}

From 1892 through 1988, annual lobster landings fluctuated between 17-361 tons for LFA 35 and 50-962 tons for LFA 36 (Fig. 2). Most of the seasonal catch occurred during the first month (autumn) and last month (spring) of the lobster fishing seasons (Fig. 3). Fishing ceased during the winter in both areas because of the harsh winter conditions and a decrease in lobster catchability due to colder water (McLeese and Wilder, 1958).

\section{Size frequencies}

Geographic differences. In Passamaquoddy Bay and in the upper part of the Bay of Fundy, i.e. Alma and Halls Harbour, the mean size of lobsters was generally larger than in St. Martins, Beaver Harbour, Chance Harbour and Delap Cove during October-November 1979 (Fig. 4). In Beaver Harbour, Chance Harbour, St.

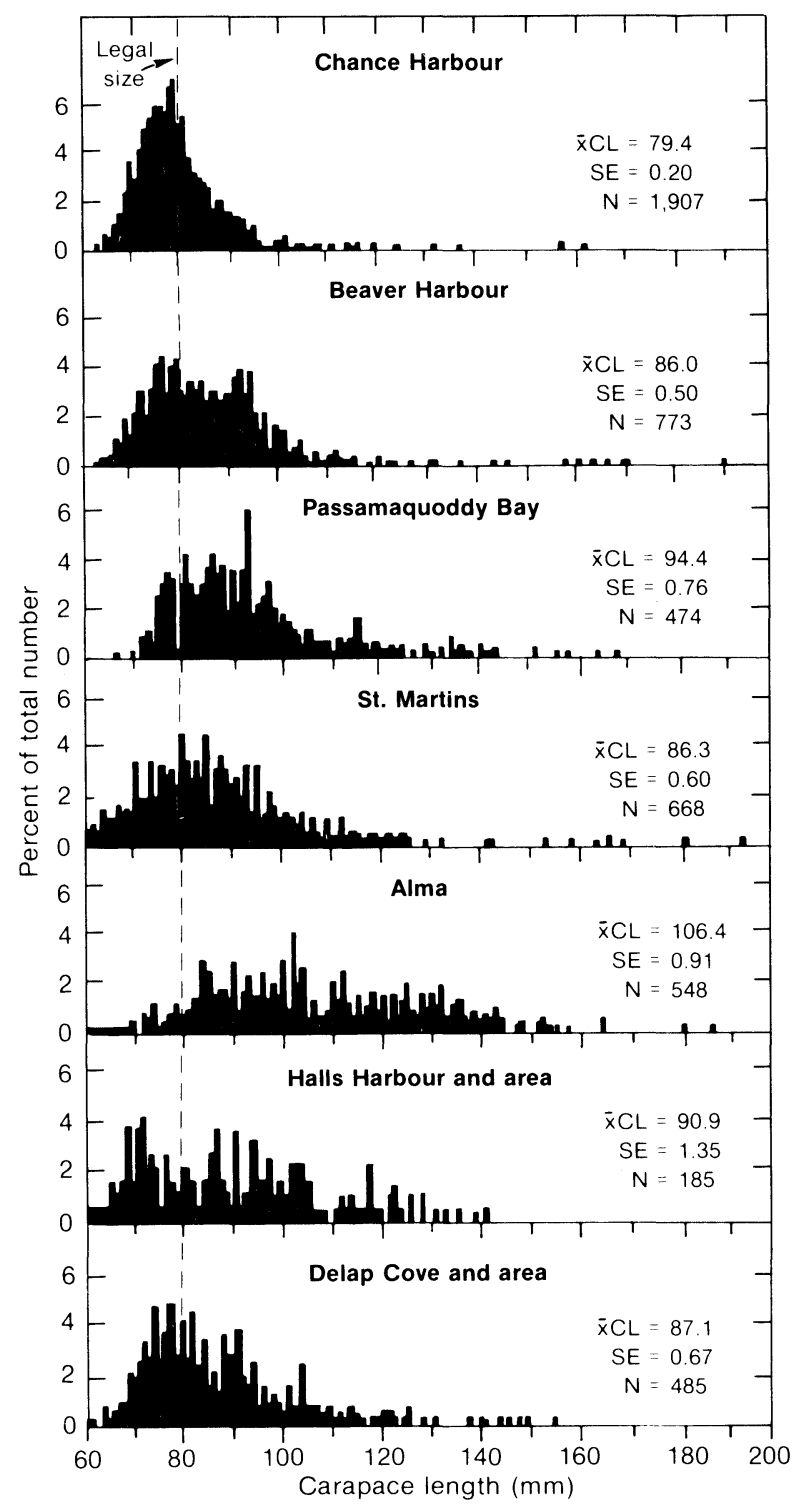

Fig. 4. Size frequencies as a percentage of total number of lobsters in each 1-mm carapace length size class for at-sea, trapcaught lobsters in the Bay of Fundy during OctoberDecember $1978(\bar{x} C L=$ mean carapace length; $S E=$ standard error; $\mathrm{N}=$ total number of lobsters). 


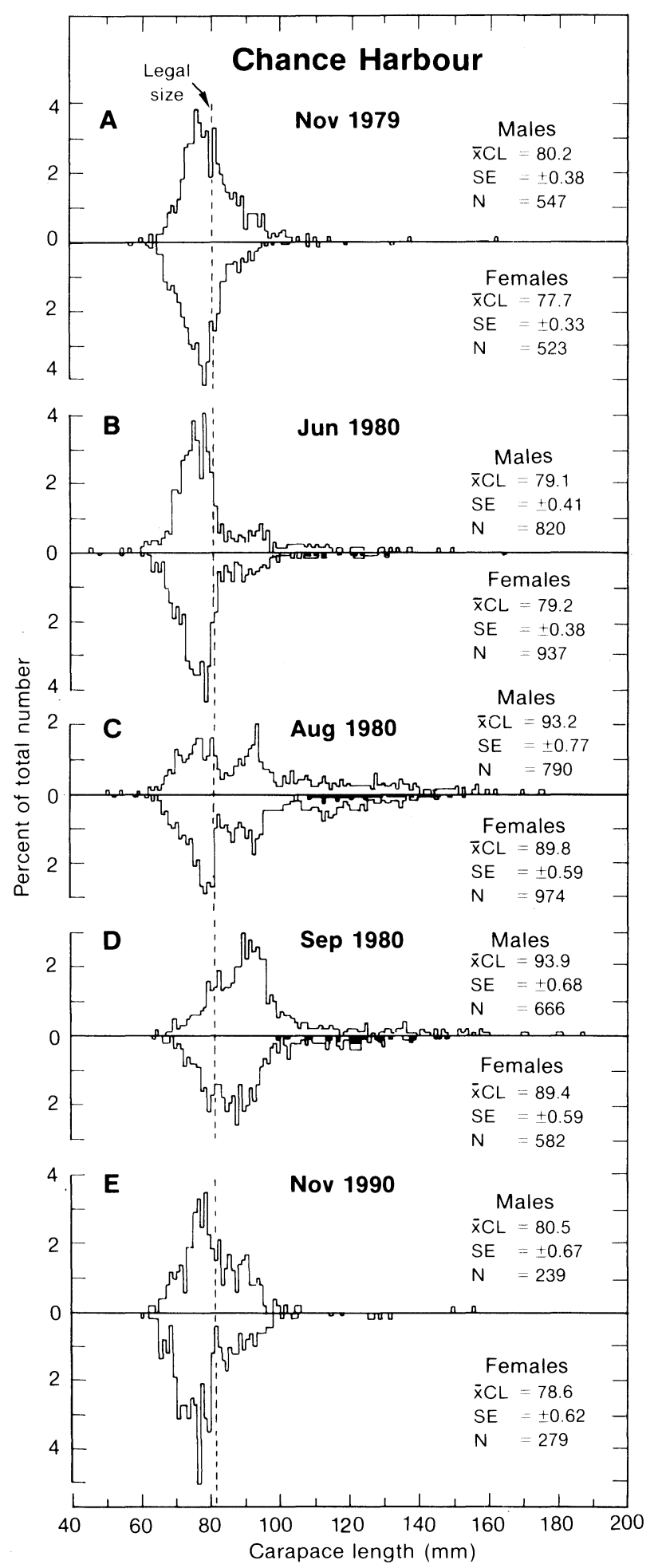

Fig. 5. Seasonal changes in size frequencies as a percentage of total number of male, non-berried female (light histograms) and berried female (dark histograms) lobsters in each 1-mm size class obtained at-sea near Chance Harbour, 1979-80 ( $\bar{x} C L=$ mean carapace length; $\mathrm{SE}=$ standard error; $\mathrm{N}=$ total number of lobsters).
Martins and Delap Cove, the size structure of trapcaught lobsters consisted mainly of prerecruits (70-80 $\mathrm{mm} \mathrm{CL}$ ) and of recently recruited lobsters (81-94 $\mathrm{mm}$ $\mathrm{CL})$ whereas in Passamaquoddy Bay and the upper part of the Bay of Fundy, a larger proportion of the trap-caught lobsters consisted of large, mature lobsters greater than $94 \mathrm{~mm} \mathrm{CL}$ (Fig. 4).

Seasonal changes. In Chance Harbour and Alma, the size structure of trap-caught lobsters changed in the season (Fig. 5, 6). In Chance Harbour, there was an increase in the proportion of first molt lobsters into the fishery (81-94 $\mathrm{mm} \mathrm{CL}$ ) in addition to an increase in number of berried females and mature lobsters (>94 $\mathrm{cm} \mathrm{CL}$ ) during August and September (Fig. 5C, D). In Alma, the size structure of trap-caught lobsters was characterized by an increase in the number of berried

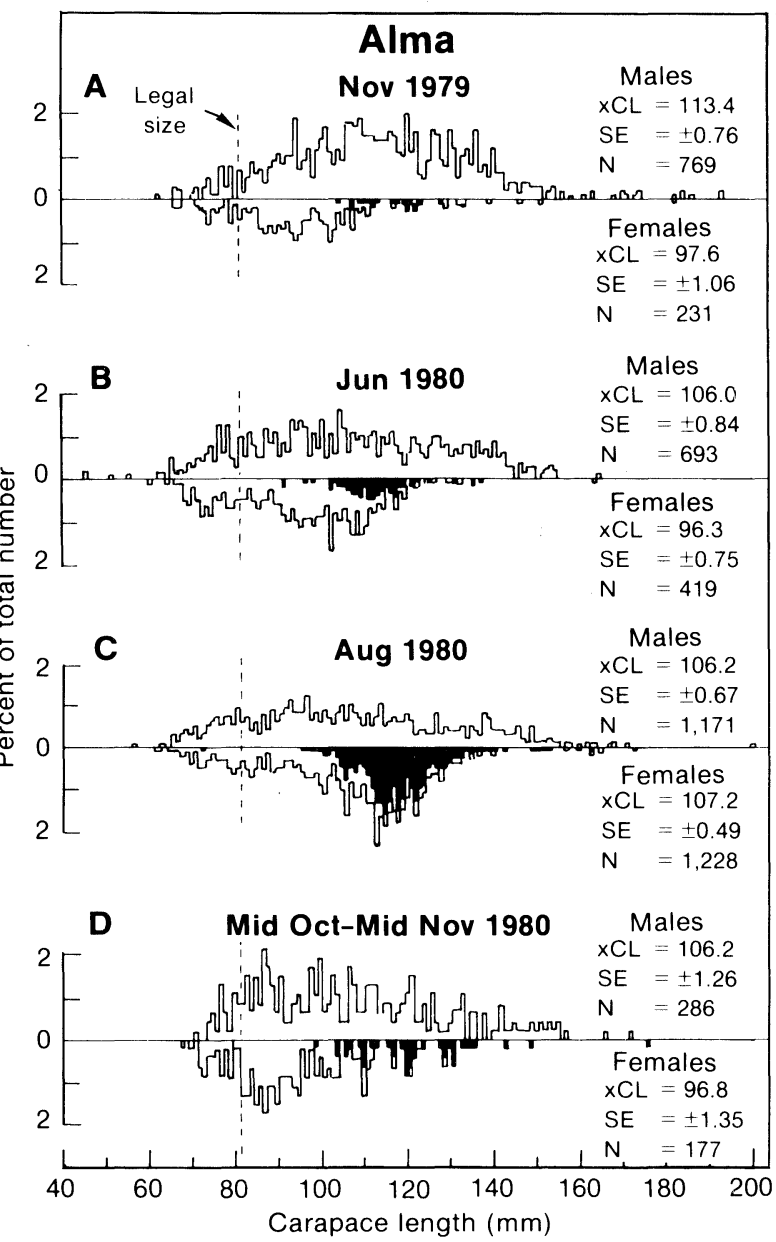

Fig. 6. Seasonal changes in size frequencies as a percentage of total number of male, non-berried female (light histograms) and berried female (dark histograms) lobsters in each 1-mm size class obtained at-sea near Alma, $1979-80(\bar{x} C L=$ mean carapace length; $\mathrm{SE}=$ standard error; $\mathrm{N}=$ total number of lobsters). 
females during summer (Fig. 6B, C). In both areas and for both sexes, the mean length of legal size lobsters $(\geqslant 81 \mathrm{~mm} \mathrm{CL})$ increased during the summer months
(Fig. 7A) and the number of males, females and berried lobsters per-trap-haul was significantly $(P>0.05)$ higher during September (Fig. 7B).

\section{Alma}

\section{Chance Harbour}

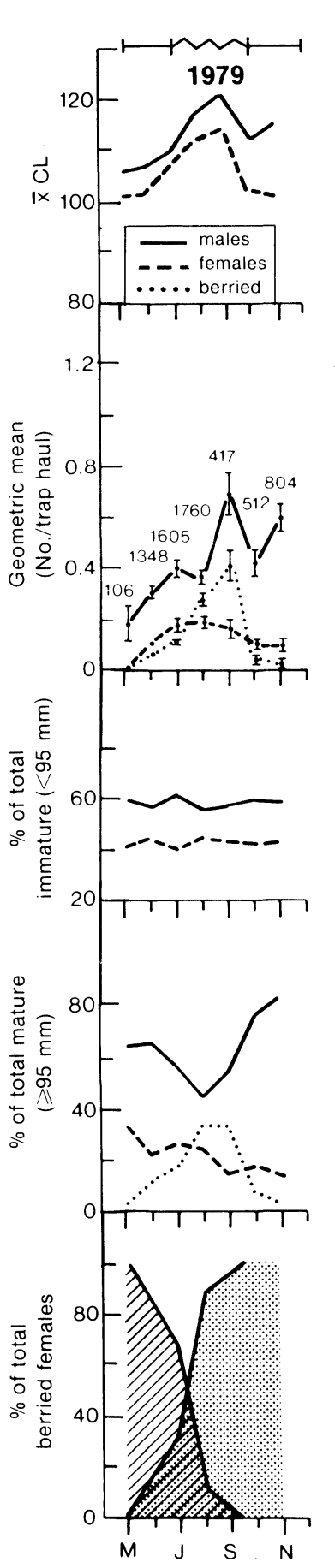

Fishing Season $(\longmapsto=$ open; $M$ = closed $)$

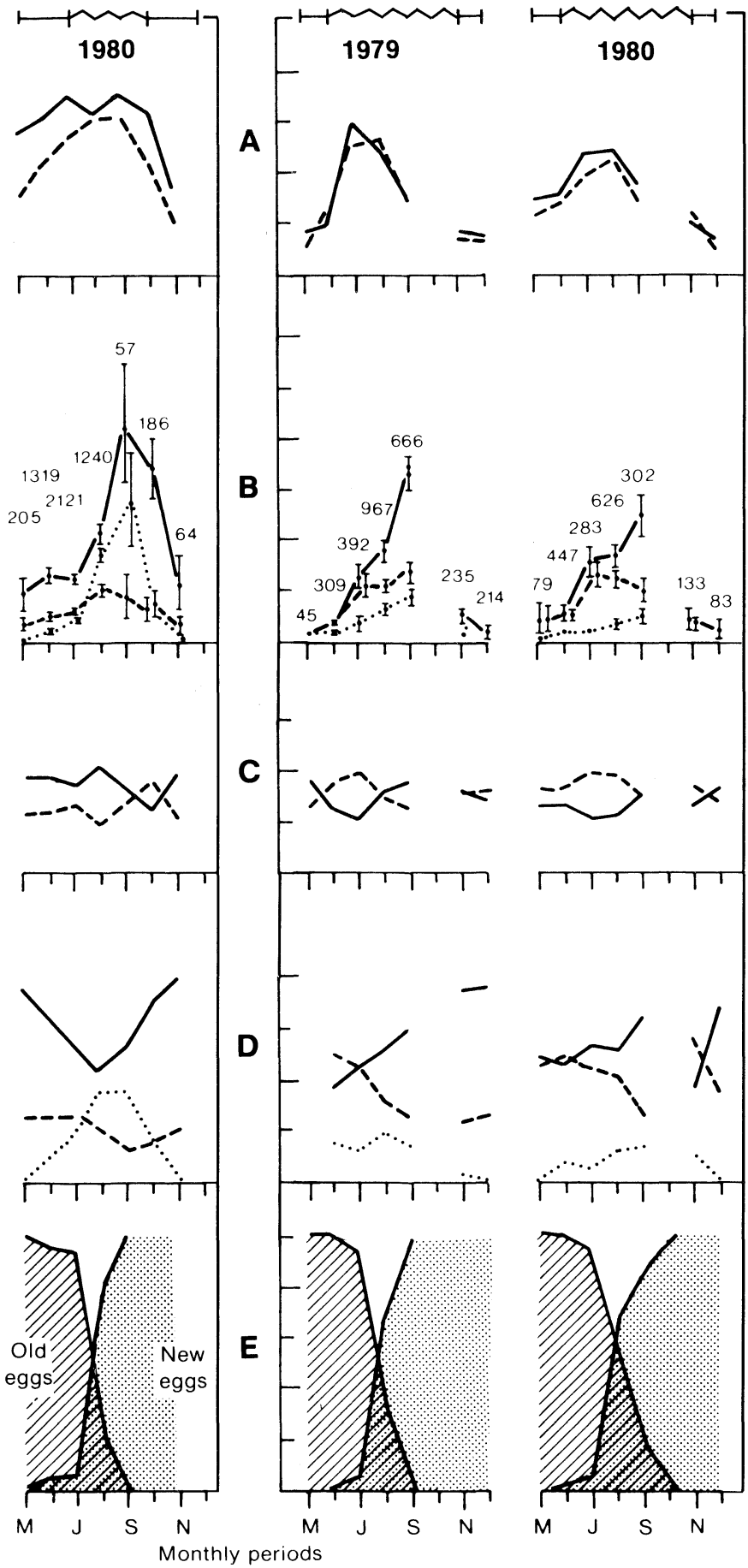

Fig. 7 Monthly mean for (A) carapace length of legal-size lobsters ( $\geqslant 81 \mathrm{~mm} \mathrm{CL}$ ); (B) number of legal-size lobsters ( $\geqslant 81 \mathrm{~mm} \mathrm{CL}$ ) per-trap-haul (vertical lines are $95 \%$ confidence limits and numbers above them are number of trap hauls); (C) sex ratios as percent of total immature lobsters $<95 \mathrm{~mm} \mathrm{CL}$; (D) sex ratios are percent of total mature lobsters $(\geqslant 95 \mathrm{~mm} \mathrm{CL}$ ); and $(\mathbf{E})$ percent of berried females with new (without eye spot) and old (with eye spot); from at-sea samples of traps near Alma and Chance Harbour 1979-80. 


\section{Sex ratio}

Seasonal sex ratio of newly recruited lobsters (81-94 $\mathrm{mm} \mathrm{CL}$ ) in the Alma area fluctuated between 53 and $61 \%$ in favour of males throughout 1979 and 1980 , with one exception during 1980, when the percentage of males decreased to $45 \%$ (Fig. $7 \mathrm{C}$ ). In the Chance Harbour area, however, the sex ratio of newly recruited lobsters (81-94 $\mathrm{mm} \mathrm{CL}$ ) was not as consistent and there were more females for most of both years; the percentage of males fluctuated between a low of $41 \%$ during July of both years to a high of $55 \%$ (Fig. $7 \mathrm{C}$ ).

In Alma, the proportion of mature male lobsters ( $\geqslant 95 \mathrm{~mm} \mathrm{CL}$ ) was highest during the October-November and May-July fishing periods, whereas the higher proportion of females, especially berried females, was found during August-September (Fig. 7D). In contrast, in the Chance Harbour area, the highest ratio of large males ( $\geqslant 95 \mathrm{~mm} \mathrm{CL}$ ) were found during the July-September period. However, as in the Alma area, the highest percentage of berried females was caught during the July-September sampling period (Fig. 7D).
Based on the occurrence of eggs in advance stage of development and the presence of empty egg cases still attached to berried females, it was estimated that hatching began late May-early June and lasted until August and September, while females with mature ovaries began extruding new eggs by late August through September (Fig. 7E). Egg hatching and extrusion occurred 1-2 weeks earlier in the Alma area compared to that at Chance Harbour (Fig. 7E).

\section{Annual changes}

Catch data collected during 1979-88 in the Chance Harbour (November-December and June) and Alma (October-November and July) areas during the autumn and spring lobster fishing seasons showed yearly fluctuations and differences in the number of lobster per-trap-haul between autumn and spring (Fig. $8 A)$. At Alma, there were significantly higher numbers (ANOVA, $P<0.01$ ) of mature lobsters $(\geqslant 95 \mathrm{~mm} \mathrm{CL}$ ) and new recruits (81-94 $\mathrm{mm} \mathrm{CL})$ than prerecruits (75-80 $\mathrm{mm} \mathrm{CL}$ ), except during the autumn 1986 and spring 1987 (Fig. 8A). A significantly higher number (ANOVA, $\mathrm{P}<0.01)$ of prerecruits $(75-80 \mathrm{~mm} \mathrm{CL})$ and new recruits

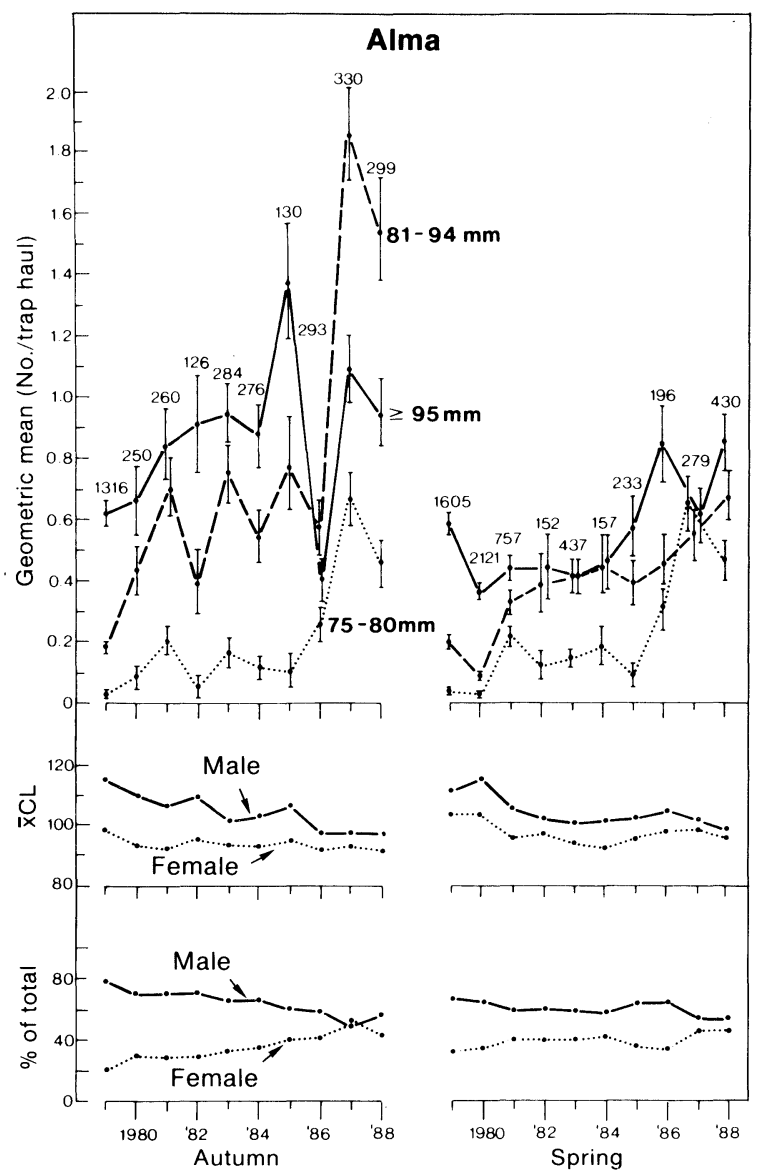

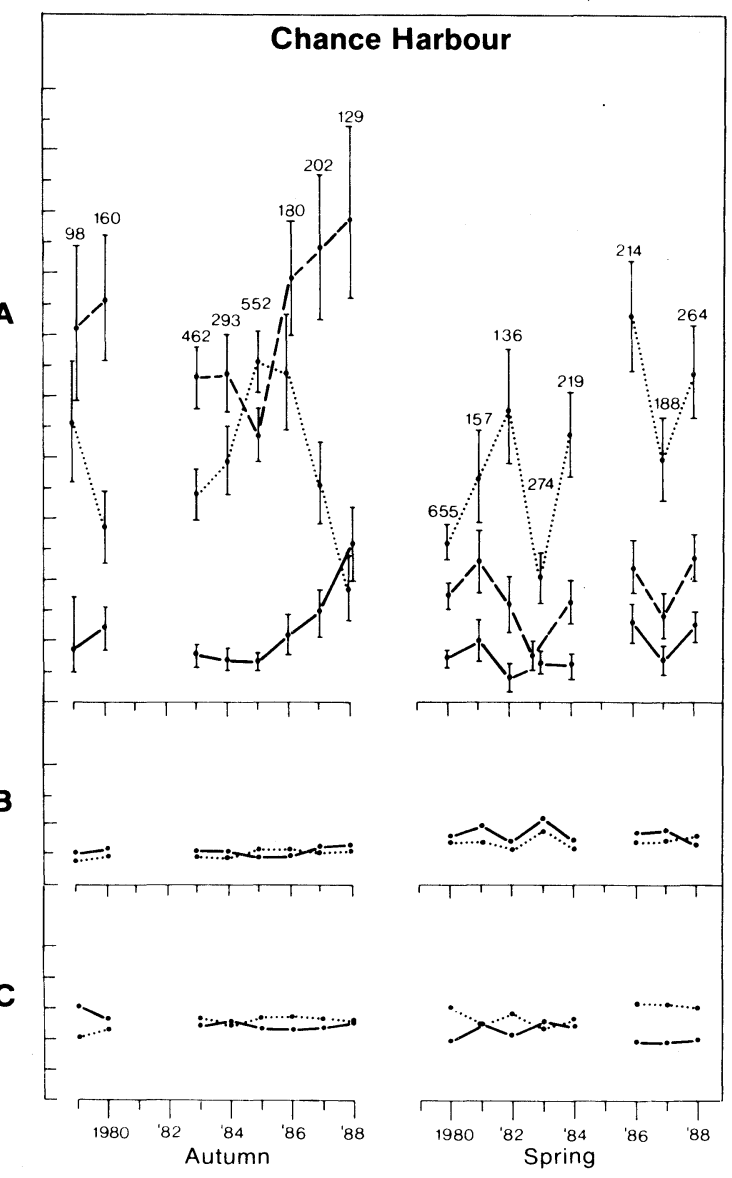

Fig. 8. Yearly mean for (A) number of lobsters by size groups per-trap-haul (vertical lines are $95 \%$ confidence limits and numbers above them are the number of trap hauls); (B) carapace length of legal-size lobsters ( $\geqslant 81 \mathrm{~mm} \mathrm{CL}$ ), from at-sea samples of traps near Alma and Chance Harbour for 1979-88; and (C) sex ratios as percent of total legal-size lobsters ( $\geqslant 81 \mathrm{~mm} C L$ ). 
(81-94 mm CL) were caught at Alma during 1987, compared to other years (Fig. 8A), which was in accordance with the increase in catches experienced for LFA 35 (Fig. 2). In contrast, at Chance Harbour, from year to year, there were significantly more prerecruits and recruits (ANOVA, $P<0.01$ ) than mature lobsters for both autumn and spring except during autumn 1988 and spring 1983. Furthermore, during spring, there were significantly more prerecruits (ANOVA, $P<0.01$ ) than all legal-size lobsters (Fig. 8A).

At both areas, from year to year, the number of legal-size lobsters $(\geqslant 81 \mathrm{~mm} \mathrm{CL})$ per-trap-haul was always higher in the autumn than the following spring (Fig. 8A).

The mean $\mathrm{CL}$ of males $(\geqslant 81 \mathrm{~mm} \mathrm{CL}$ ) was generally larger than females (Fig. 8B). At Alma, the difference in mean size between males and females has decreased since 1979. During this period, the mean size of males had decreased by $19 \mathrm{~mm} \mathrm{CL}$ during autumn and $17 \mathrm{~mm}$ $\mathrm{CL}$ during spring (Fig. 8B). Furthermore, in the same area, the proportion of males had declined from 79 to $57 \%$ during autumn and 67 to $54 \%$ during spring (Fig. $8 \mathrm{C})$. However, this trend was not evident in the Chance Harbour area (Fig. 8B, C).

\section{Discussion}

The size frequencies of trap-caught lobsters in the Bay of Fundy showed clear geographic differences and both annual and seasonal trends. However, caution is required in interpreting trap data due to the many factors that can influence trap selectivity, for example soak time, trap and bottom types (Dow, 1961; Thomas, 1973; Austin, 1977; Skud, 1979; Fogarty and Borden, 1980; Estrella and McKiernan, 1989; Miller, 1989) and lobster catchability which is affected by temperature conditions and the animal's physiological state (McLeese and Wilder, 1958; Elner, 1980; Miller, 1989). Nevertheless, some useful biological and fishery information can be derived from an examination of the size frequencies.

Geographic variation in the size distribution of trap-caught lobsters has been recorded in other areas of the Maritime Provinces of Canada (Templeman, 1936, Campbell and Pezzack, 1986). The differences in the size structure of lobsters found in the upper compared to the lower Bay of Fundy, are likely due to differences in bottom topography (Fader et al., 1977) along with differences in current speed and levels of benthic productivity (Fader et al., 1977; Wildish and Peer, 1983; Wildish et al., 1983; Emerson et al., 1986). The upper Bay of Fundy is mainly composed of flat sandy substrate called Sambro sand, whereas the Chance Harbour area has more of a silty substrate called LaHave clay with rocky outcrops (Fader et al., 1977; Emerson et al., 1986). Also, there are larger tides and, consequently, greater currents in the upper half compared to the lower half of the Bay of Fundy (Wildish and Peer, 1983). Substrate types and current strength are known to have a major influence on the size frequencies of lobsters (Howard, 1980; Howard and Nunny, 1983). The settlement of postlarval lobsters (Cobb et al., 1989) and subsequent survival of juveniles to legal size seem more successful in rocky and silty substrate areas (Pottle and Elner, 1982) such as can be found in the Chance Harbour area (Fader et al., 1977; Emerson et al., 1986). However, at present the source of lobster larvae and the associated water current patterns that contribute to larval settlement in the Bay of Fundy are unknown (Campbell, 1985).

Seasonal change in size and sex composition of lobsters caught by traps in the Bay of Fundy was clearly seen in this study. The seasonal changes observed at Alma and Chance Harbour probably reflect in part the deep-shallow migration pattern of large mature lobsters (based on tagging studies by Campbell (1986) and Campbell and Stasko (1986)) that occurs throughout the Bay of Fundy during spring and autumn. During spring, mature lobsters migrate into the warm (up to $15^{\circ} \mathrm{C}$ ) shallow depths $(<120 \mathrm{~m})$ of the Bay of Fundy to molt, release eggs, extrude new eggs and mate. During autumn, when the water temperature begins to decrease, mature lobsters return to deeper water $(>120$ $\mathrm{m})$ where the bottom temperature will remain between $1^{\circ}$ and $7^{\circ} \mathrm{C}$ during winter (Campbell and Stasko, 1986). This migratory pattern has been attributed to the maximization of degree-day heat units for the physiological needs of molting, growth, gonadal development, egg extrusion (Cooper and Uzmann, 1980) and egg development (Campbell and Stasko, 1985, 1986; Campbell, 1986).

Other factors that could have contributed to the observed change in size-frequency distributions were, lobster molting during the summer period (July-September, Fig. 5C, D) (Campbell, 1983) and variable exploitation rates which could vary from 50 to $90 \%$ (Campbell, 1980). In areas of higher exploitation, the number of lobsters per-trap-haul and the size distribution of lobsters can be significantly changed after only a few weeks of fishing, compared to areas of lower exploitation where the catch and size composition of lobsters would remain more stable for longer periods of time. Consequently, variability in the data is more likely to occur in areas of higher exploitation if sampling is not carried out at precise time periods after the opening of the fishing season. However, although the original scheduling of the at-sea sampling did not take into consideration the level of exploitation among the different areas, the timing of the at-sea sampling would have minimized this bias on the lobster size frequencies and on the catch rate. 
The factors controlling the annual variability in landings and mean sizes are not fully understood, but temperature appears to play a major role. Various studies have shown that temperature may affect lobster landings (Flowers and Saila, 1972; Dow, 1977, 1978; Fogarty, 1988). Also, part of the variability in lobster catch in the upper reaches of the Bay of Fundy may be due to the seasonal deep-shallow migration of large mature lobsters. From year to year, during autumn and spring, depending mainly on water temperature, this migration can occur during a 2- to 3-week period (Campbell and Stasko, 1986). Thus, depending on when the at-sea sampling is undertaken, the size composition of the catch and the number of lobsters pertrap-haul could be significantly altered. In contrast to Alma, in areas like Chance Harbour, the landings are mainly composed of recruits entering the fishery each year. Consequently, fluctuations in landings and catch rate should depend mainly on annual recruitment. However, a sharp decline observed in the autumn index in 1987 and 1988 off Chance Harbour (Fig. 8A) contrasts with the spring pattern for this area and seems inconsistent, with a continuing increase in autumn abundance of legal-size lobsters. This suggests that in some years reduced availability rather than lower recruitment may be important.

In the Alma area, the mean size and sex ratio of legal-size males ( $\geqslant 81 \mathrm{~mm} \mathrm{CL}$ ) have decreased substantially compared to females since 1979 (Fig. 8B, C). This decline could be due to an increase in the number of newly recruited males $(81-94 \mathrm{~mm} \mathrm{CL})$ in combination with higher exploitation of larger males ( $\geqslant 95 \mathrm{~mm} \mathrm{CL}$ ) compared to females. Females are protected from the fishery when carrying eggs and also according to a tagging study by Campbell and Stasko (1986), mature females tended to migrate off the fishing grounds earlier than mature males, making males more vulnerable to fishing. However, probably due to the large number of immature lobsters, a similar trend was not noticeable in the Chance Harbour area (Fig. 8B, C).

The differences observed in the timing (1-2 weeks earlier in Alma compared to Chance Harbour) of hatching and extrusion of eggs was apparently due to temperature differences between areas. According to Campbell (MS 1986), the bottom water temperature during the summer of 1979 and 1980 reached $15^{\circ} \mathrm{C}$ off Alma compared to $12^{\circ} \mathrm{C}$ off Chance Harbour. Embryological development rates of lobster eggs are closely related to temperature (Templeman, 1940; Perkins, 1972), as is the onset of larval hatching (Ennis, 1975). Consequently, the lower water temperature in the Chance Harbour area would have delayed egg development, whereas the warmer water temperature in the upper part of the Bay of Fundy would have had the opposite effect.

\section{Acknowledgements}

We thank D. E. Graham, D. Duggan, S. Hamet, A. Williamson and many Bay of Fundy fishermen for their technical assistance; F. Cunningham for illustrations; B. Best and J. Hurley for typing; P. Lawton and G. Pohle for helpful comments on this paper.

\section{References}

AUSTIN, C. B. 1977. Incorporating soak time into measurement of fishing effort in trap fisheries. Fish. Bull. U.S., 75(1): 213-218.

BARLOW, J., and J. RIDGWAY. 1971. Polymorphisms of esterase isozymes in the American lobster (Homarus americanus). J. Fish. Res. Board Can., 28: 15-21.

BENNETT, D. B. 1974. The effect of pot immersion time on catches of crabs, Cancer pagurus L. and lobsters, Homarus gammarus (L.). ICES J. Cons., 35: 332-336.

BENNETT, D. B., and D. G. BROWN. 1979. The problems of pot immersion time in recording and analysing catcheffort data from a trap fishery. ICES Rapp. Proc.-Verb., 175: 186-189.

BENNETT, D. B., and S. R. J. LOVEWELL. 1977. The effects of pot immersion time on catches of lobsters, Homarus gammarus (L), from the Welsh coast fishery. Fish. Res. Tech. Rep. MAFF Direct. Fish Res., Lowestoft, 36, 4 p.

CAMPBELL, A. 1980. A review of mortality estimates of lobster populations in the Canadian Maritimes. Can. Tech. Rep. Fish. Aquat. Sci., 932: 27-35.

1983. Growth of tagged American lobsters, Homarus americanus, in the Bay of Fundy. Can. J. Fish. Aquat. Sci., 40: $1667-1675$.

1984. Aspects of lobster biology and fishery in the upper reaches of the Bay of Fundy. Can. Tech. Rep. Fish. Aquat. Sci., 1256: 469-488.

1985. Application of yield and egg-per-recruit model to the lobster fishery in the Bay of Fundy. Nor. Amer. J. Fish. Manage., 5: 91-104.

1986. Migratory movements of ovigerous lobsters, Homarus americanus, tagged off Grand Manan, eastern Canada. Can. J. Fish. Aquat. Sci., 43: 2197-2205.

MS 1986. On the change in fishing season in Lobster District 1 (36). CAFSAC Res. Doc., No. 49, 27 p.

1989. The lobster fishery of southwestern Nova Scotia and the Bay of Fundy. In: Scientific approaches to management of shellfish resources, J. F. Caddy (ed.). Wiley \& Sons, New York, N.Y., p. 141-158.

CAMPBELL, A., and R. K. MOHN. 1983. Definition of American lobster stocks for the Canadian Maritimes by analysis of fishing-landing trends. Trans. Amer. Fish. Soc., 112: 744-759.

CAMPBELL, A., and D. S. PEZZACK. 1986. Relative egg production and abundance of berried lobsters, Homarus americanus, in the Bay of Fundy and off southwestern Nova Scotia. Can. J. Fish. Aquat. Sci., 43: 2190-2196.

CAMPBELL, A., and A. B. STASKO. 1985. Movements of tagged American lobsters, Homarus americanus, off southwestern Nova Scotia. Can. J. Fish. Aquat. Sci., 42 : 229-238. 
1986. Movements of lobsters (Homarus americanus) tagged in the Bay of Fundy, Canada. Mar. Biol., 92: 393404.

COBB, J. S., D. WANG, and D. B. CAMPBELL. 1989. Timing of settlement by postlarval lobsters (Homarus americanus): field and laboratory evidence. J. Crust. Biol., 9: 60-66.

COOPER, R. A., and J. R. UZMANN. 1971. Migrations and growth of deep-sea lobsters, Homarus americanus. Science (Washington, D.C.), 171: 288-290.

1980. Ecology of juvenile and adult Homarus. In: Biology and management of lobsters, J. S. Cobb and B. F. Phillips (eds.). Academic Press, New York, N.Y., Vol. 2, p. $97-142$.

DOW, R. L. 1961. Some factors influencing Maine lobster landings. Comm. Fish. Rev., 23: 1-11.

1977. Relationship of sea surface temperature to American and European lobster landings. ICES J. Cons., 37: 186-190.

1978. Effects of sea surface temperature cycles on landings of American, European and Norway lobsters. ICES J. Cons., 38: 271-272.

DUNCAN, D. B. 1955. Multiple range and multiple $F$ tests. Biometrics, 11: 1-42.

ELNER, R. W. 1980. Lobster gear selectivity. Can. Tech. Rep. Fish. Aquat. Sci., 932: 77-83.

EMERSON, G. W., J. C. ROFF, and D. J. WILDISH. 1986 Pelagic-benthic energy coupling at the mouth of the Bay of Fundy. Ophelia, 26: 165-180.

ENNIS, G. P. 1975. Observations on hatching and larval release in the lobster Homarus americanus. J. Fish. Res. Board Can., 32: 2210-2213.

ESTRELLA, B. T., and D. J. McKIERNAN. 1989. Catch-perunit-effort and biological parameters from the Massachusetts coastal lobster resource: description and trends. NOAA Tech. Rep., NMFS 81, 21 p.

FADER, G. B., L. H. KING, and S. B. MacLEAN. 1977. Surficial geology of the eastern Gulf of Maine and Bay of Fundy. Mar. Sci. Pap. 19. Geo. Surv. Can. Pap. 76-17: 23 p. + Chart.

FLOWERS, J. M., and S. B. SAILA. 1972. Analysis of temperature effects on the inshore lobster fishery. J. Fish. Res. Board Can., 29: 1221-1225.

FOGARTY, M. J. 1988. Time series models of the Maine lobster fishery: the effect of temperature. Can. J. Fish. Aquat. Sci., 45: 1145-1153.

FOGARTY, M. J., and D. V. D. BORDEN. 1980. Effects of trap venting on gear selectivity in the inshore Rhode Island lobster fishery. Fish. Bull. U.S., 77: 925-933.

HARDING, G. C., K. F. DRINKWATER, and W. P. VASS. 1983. Factors influencing the size of American lobster (Homarus americanus) stocks along the Atlantic coast of Nova Scotia, Gulf of St. Lawrence, and Gulf of Maine: a new synthesis. Can. J. Fish. Aquat. Sci., 40: 168-184.

HOWARD, A. E. 1980. Substrate controls on the size composition of lobster (Homarus americanus) populations. ICES J. Cons., 39: 130-133.

HOWARD, A. E., and R. S. NUNNY. 1983. Effects of near-bed current speeds on the distribution and behavior of the lobster Homarus gammarus (L.), J. Exp. Mar. Biol. Ecol., 71: $27-42$.
KROUSE, J. S. 1978. Effectiveness of escape vent shape in traps for catching legal-sized lobsters, Homarus americanus, and harvestable-sized crabs, Cancer borealis and Cancer irroratus. Fish. Bull. U.S., 76(2): 425-432.

1980. Summary of lobster, Homarus americanus, tagging studies in American waters (1898-1978). Can. Tech. Rep. Fish. Aquat. Sci., 932: 132-140.

KROUSE, J. S., and J. C. THOMAS. 1975. Effects of trap selectivity and some population parameters on size composition of the American lobster, Homarus americanus, catch along the Maine coast. Fish. Bull. U.S., 73: 862-871.

MCLEESE, D. W., and D. G. WILDER. 1958. The activity and catchability of the lobster (Homarus americanus) in relation to temperature. J. Fish. Res. Board Can., 15: 1345-1354.

MILLER, R. J. 1989. Catchability of American lobsters (Homarus americanus) and rock crabs (Cancer irroratus) by traps. Can. J. Fish. Aquat. Sci., 46: 1652-1657.

1990. Effectiveness of crab and lobster traps. Can. J. Fish. Aquat. Sci., 47: 1228-1251.

ODENSE, P. H., and C. ANNAND. MS 1978. Isoenzyme systems of an inshore and offshore lobster population. ICES C.M. Doc., No. K:15.

PERKINS, H. C. 1972. Development rates at various temperatures of embryos of the northern lobster (Homarus americanus Milne-Edwards). Fish. Bull. U.S., 70: 95-99.

POTTLE, R. A., and R. W. ELNER. 1982. Substrate preference behaviour of juvenile American lobsters, Homarus americanus, in gravel and silt-clay sediments. Can. J. Fish. Aquat. Sci., 39: 928-932.

SKUD, B. E. 1979. Soak time and the catch per pot in an offshore fishery for lobsters, Homarus americanus. In: Population assessment of shellfish stocks, $\mathrm{H}$. J. Thomas (ed.). ICES Rapp. Proc.-Verb., 175: 190-196.

STASKO, A. B. 1980. Lobster larval surveys in Canada. Can. Tech. Rep. Fish. Aquat. Sci., 932: 157-169.

STASKO, A. B., and A. CAMPBELL. 1980. An overview of lobster life history and fishery in southwestern Nova Scotia. Can. Tech. Rep. Fish. Aquat. Sci., 954: 208-244.

TEMPLEMAN, W. 1936. Larval differences in the life history of the lobster (Homarus americanus) on the coast of the Maritime Provinces of Canada. J. Biol. Board Can., 2: 41-87.

1940. Embryonic developmental rates and egg-laying of Canadian lobsters. J. Fish. Res. Board Can., 5: 71-83.

THOMAS, J. C. 1973. An analysis of the commercial lobster fishing along the coast of Maine. NOAA Tech. Rep., NMFS SSRF, 667, $57 \mathrm{p}$

TRACEY, L., K. NELSON, D. HEDGECOCK, R. A. SHLESER, and M. L. PRESSICK. 1975. Biochemical genetics of lobsters: genetic variation and the structure of American lobster (Homarus americanus) populations. J. Fish. Res. Board Can., 32: 2091-2101.

WILDISH, D. J., and D. PEER. 1983. Tidal current speed and production of benthic macrofauna in the lower Bay of Fundy. Can. J. Fish. Aquat. Sci., 40(Supple. 1): 309-321.

WILDISH, D. J., D. L. PEER, A. J. WILSON, J. HINES, L. LINKLETTER, and M. J. DADSWELL. 1983. Sublittoral macro-infauna of the upper Bay of Fundy. Can. Tech. Rep. Fish. Aquat. Sci., 1194: iii +64 p. 
